\title{
DNA synthesis in human rheumatoid and nonrheumatoid synovial lining
}

\author{
L. A. COULTON,* B. HENDERSON, LUCILLE BITENSKY, \\ AND J. CHAYEN
}

From the Division of Cellular Biology, Mathilda and Terence Kennedy Institute of Rheumatology, Bute Gardens, London, W6 7DW

SUMMARY The DNA content per nucleus has been measured in the lining cells of 12 specimens of rheumatoid and 12 of nonrheumatoid synovial tissue. Optimal conditions for this reaction on these cells have been defined, and an index of DNA synthesis has been applied to give a quantitative measure of the degree of synthesis. This has given evidence of some DNA synthesis in both types of synoviocytes, compatible with the amount found in a slowly self-replacing tissue. There was no difference in the amount of synthesis in the rheumatoid and nonrheumatoid synoviocytes.

Mohr et al. ${ }^{1}$ reviewed the evidence indicating that, although hyperplasia of the synovial lining is an early and characteristic feature of rheumatoid arthritis, mitosis is very rarely seen in the synoviocytes. In our own studies on over 600 specimens of rheumatoid synovial tissue a few mitotic figures were found in the villi of only one. Various attempts have been made to study the cellular kinetics of the synoviocytes to resolve this apparent paradox, namely, of hyperplasia without obvious mitosis., 2 In some of these studies the DNA content of cells isolated from human synovial tissue has been measured. ${ }^{2}$ Mohr et al. ${ }^{1}$ and Nykänen et al. ${ }^{3}$ used small blocks of synovium which they incubated in vitro with tritiated thymidine; it may be argued that such invitro procedures alter the physiological state of the synoviocytes and hence make the results difficult to relate to what occurred in life. There is now ample evidence ${ }^{4}$ that Feulgen cytophotometry, done on sections of tissue, permits adequate analysis of the cell kinetics of cell populations in that tissue, as occurred in life. Moreover, unlike the use of isolated cells, it has the advantage of permitting precise histological and topographical definition of the cells which are analysed.

Accepted for publication 1 June 1979

*Present address: Department of Chemical Pathology, University of Sheffield Medical School, Beech Hill Road, Sheffield S10 2RX.

Correspondence to Dr J. Chayen, Division of Cellular Biology, Kennedy Institute of Rheumatology, Bute Gardens, London W6 7DW.

\section{Materials and methods}

Twelve specimens of nonrheumatoid synovial tissue and 12 rheumatoid synovial specimens have been examined. The former were obtained at routine arthrotomy for internal derangements; the latter, all of classical or definite type, ${ }^{5}$ were obtained at synovectomy. The duration of the disease varied considerably, from 3 to 39 years. The ages of the male and female nonrheumatoid and rheumatoid patients were from 14 to 66 years. The time of the operations varied from 1100 to $1700 \mathrm{~h}$, most being done between 1200 and $1500 \mathrm{~h}$.

Cases $1681,1819,1823$, and 1980 were on steroids (see Table 1); 1692 and 1819 had been treated with gold; 1612 had been on penicillamine; and all the others had been treated with other nonsteroidal anti-inflammatory medications.

The specimens were cut into flat blocks, about $5 \times 3 \mathrm{~mm}$ in surface area, and chilled in N-hexane (BDH 'free from aromatic hydrocarbons' grade, boiling range $67-70^{\circ} \mathrm{C}$ ) at about $-70^{\circ} \mathrm{C}$. Within 1 minute they were transferred to cold dry glass tubes and stored at about $-70^{\circ} \mathrm{C}$ until required. They were then cut at $10 \mu \mathrm{m}$ in a Bright's cryostat with the cabinet temperature about $-25^{\circ} \mathrm{C}$ and the knife cooled with solid carbon dioxide. ${ }^{6}$ The sections were taken up on to albuminised slides and fixed for $10 \mathrm{~min}$ in acetic-ethanol $(1: 3 \mathrm{v} / \mathrm{v})$. They were then left to dry at $37^{\circ} \mathrm{C}$ overnight to ensure that the sections adhered to the slides during the prolonged acid hydrolysis. 
For the Feulgen reaction the sections were treated with $5 \mathrm{~N} \mathrm{HC1}$ at room temperature, first for various times up to $80 \mathrm{~min}$ to define the optimal time and then for $\mathbf{4 0} \mathrm{min}$ in all subsequent studies. After hydrolysis the sections were washed in $1 \mathrm{~N} \mathrm{HC1}$ and then reacted in the dark with the Schiff's reagent (R. A. Lamb) for $1 \mathrm{~h}$. They were then washed in 3 baths of acidic bisulphite, each for $3 \mathrm{~min}$, to remove unreacted leucobasic fuchsin, rinsed in distilled water, left to dry in the air, and finally mounted in Styrolite (R. A. Lamb). The details of the Feulgen reaction have been described by Chayen et al. ${ }^{6}$

\section{MEASUREMENT}

The histology was defined by normal microscopy. Generally 100 nuclei which appeared to be intact, were measured separately by means of a Vickers M85 scanning and integrating microdensitometer, with a $\times 100$ objective (NA $1 \cdot 20$ ); a scanning spot size of $0.25 \mu \mathrm{m}$ in the plane of the specimen; at a wavelength of $550 \mathrm{~nm}$. The size of the scanning field mask was just sufficient to encompass 1 nucleus, as discussed by Bitensky et al., ${ }^{7}$ and Chayen, ${ }^{8}$. The amount of reaction was expressed as relative absorption (recorded by the microdensitometer) per nucleus. Although such measurements are in arbitrary units, these units are conventional in Feulgen cytophotometry because they suffice for comparative purposes. They can be converted into absolute units of extinction per nucleus by using a standard graph which relates the relative absorption, recorded by that particular instrument, to absolute units of mean extinction and then multiplying by the projected area of the nucleus.

\section{DNA SYNTHESIS INDEX}

In the great volume of work published on Feulgen cytophotometry there has been no fully established way of quantifying the amount of DNA synthesis. The population histograms, which show the numbers of nuclei or the proportion of the population that have a particular DNA content, have to be scanned qualitatively to give an indication of the degree of DNA synthesis present in the population. Feulgen cytophotometry of nuclei in sections is rendered more complex by the fact that some of the apparently intact nuclei might have lost some of their mass by the process of sectioning. However, this is of little concern in studies on synthesis, because sectioned nuclei will contain less DNA and so will contribute to lower values; they will not be confused with nuclei having more than the diploid amount of DNA due to synthesis.

To give a quantifiable measure of DNA synthesis in a diploid population Coulton and Chayen (in preparation) derived a DNA synthesis index. This is done by subtracting the $2 \mathrm{c}$ amount from each column of the DNA population histogram; multiplying it by the number of nuclei showing this excess of DNA above the $2 \mathrm{c}$ value; and expressing this quantity relative to the $2 \mathrm{c}$ amount of DNA. So, for example, if the 2c amount of DNA is 9 units, and there are 12 nuclei which have 10 units of DNA, then the index would be $(10-9) \times 12 / 9$ or $1 \cdot 33$. In the next column of the histogram there may then be 1 nucleus with 11 units of DNA. The index for this column will be $(11-9) \times 1 / 9$ or $0 \cdot 22$. In this way the values for each column of the population histogram are determined and added together.

The DNA synthesis index for a nonproliferating tissue (rat liver) was $0 \cdot 3-0 \cdot 7$; in the basal cells of the skin of a normal guinea-pig it was 3.0-6.0, being raised above that of the nonproliferating tissue as would be expected for a layer of cells which has a low but appreciable mitotic index. In the basal cells of the skin of guinea-pigs, which was regenerating after a wound, the index was $9 \cdot 0-22 \cdot 7$, depending on the degree of regeneration. ${ }^{9}$ Thus this index does seem to give a quantitative evaluation of the degree of DNA synthesis, and the results from 2 populations can then be tested for significance by the Student's $t$ test.

\section{Results}

OPTIMAL TIME OF HYDROLYSIS

Measurements of the amount of Feulgen reaction in nuclei in sections subjected to the acid hydrolysis for various times, from 2 to $80 \mathrm{~min}$, showed that the rate at which the reaction progressed was different in nuclei of rheumatoid and nonrheumatoid synovial lining cells (Fig. 1). Thus if a single time of hydrolysis of $20 \mathrm{~min}$ were to be used, the amount of reaction recorded in the rheumatoid nuclei would be greater than in the nonrheumatoid nuclei. When this time of hydrolysis was used (Fig. 2) the results could have been taken as suggesting a difference in DNA content of these 2 types of nucleus. However, when the sections were hydrolysed for a time optimal for both types of nuclei, namely, $40 \mathrm{~min}$ (Fig. 1), the DNA content of the nuclei was identical (Fig. 3).

\section{POPULATION HISTOGRAMS}

The population histograms of the DNA content in nuclei of the synovial lining cells from rheumatoid specimens frequently showed indications of DNA synthesis (Fig. 4a). However, many of the nonrheumatoid specimens showed very similar population histograms of the DNA content of the synoviocytes (Fig. 4b). This emphasised the need for a quantifiable index of DNA synthesis to determine whether the amount of DNA synthesis was different, 


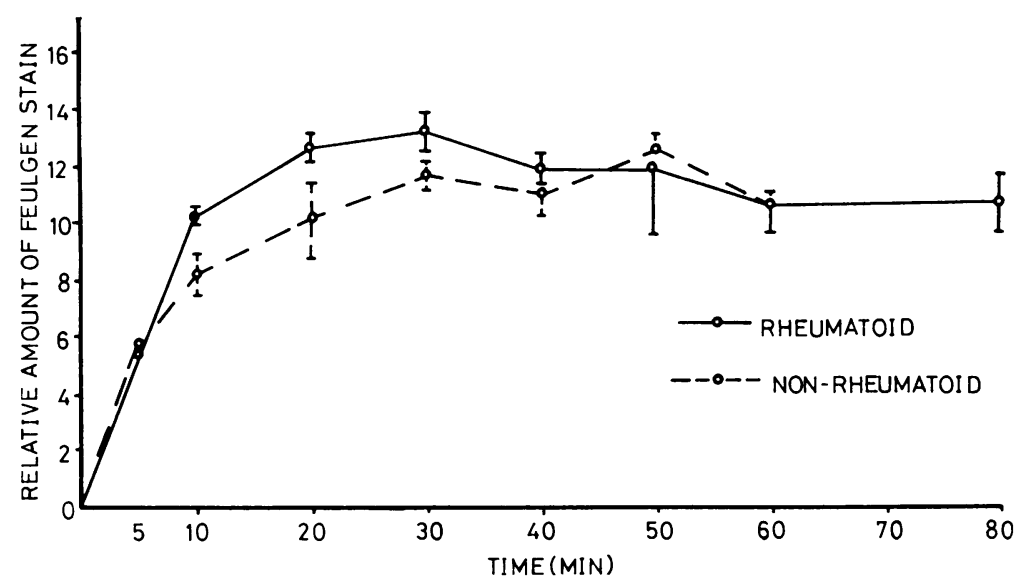

Fig. 1 The amount of Feulgen reaction in similarly sized nuclei of the lining of a specimen of rheumatoid (solid line) and a specimen of nonrheumatoid (broken line) synovial tissue subjected to various times of hydrolysis. Each point is the mean of 20 readings in each of 2 duplicate sections; the bars represent the standard deviation of all the readings.

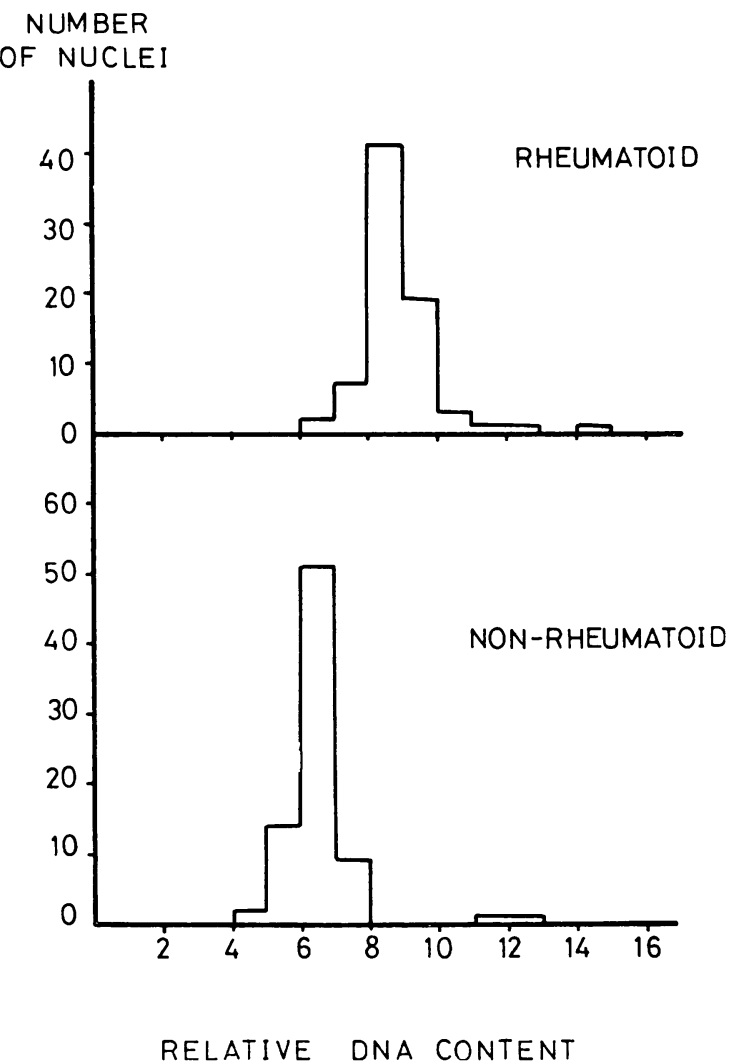

Fig. 2 Population histograms of Feulgen cytophotometry of the lining cells of rheumatoid and nonrheumatoid synovial tissue, subjected to 20 min hydrolysis. These results could have been taken to imply that the rheumatoid nuclei had more DNA than the nonrheumatoid
NUMBER

OF NUCLEI

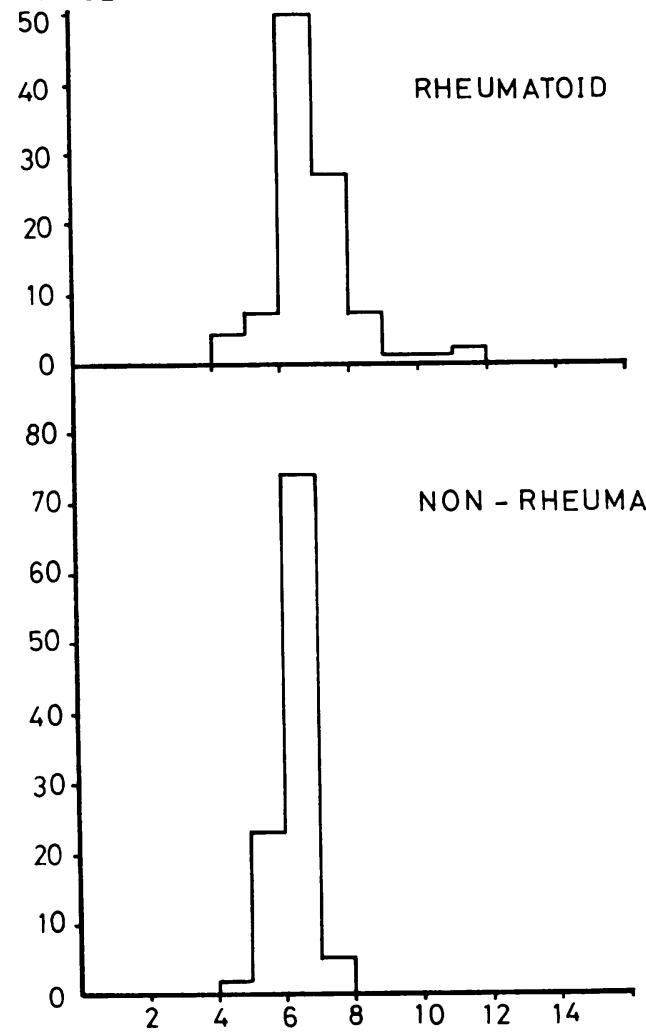

\section{RELATIVE DNA CONTENT}

Fig. 3 Population histograms of Feulgen cytophotometry of the lining cells of rheumatoid and nonrheumatoid synovial tissue subjected to hydrolysis for the optimal time. It is clear that under optimal conditions the nuclei from both types of tissue contain the same amount of DNA 


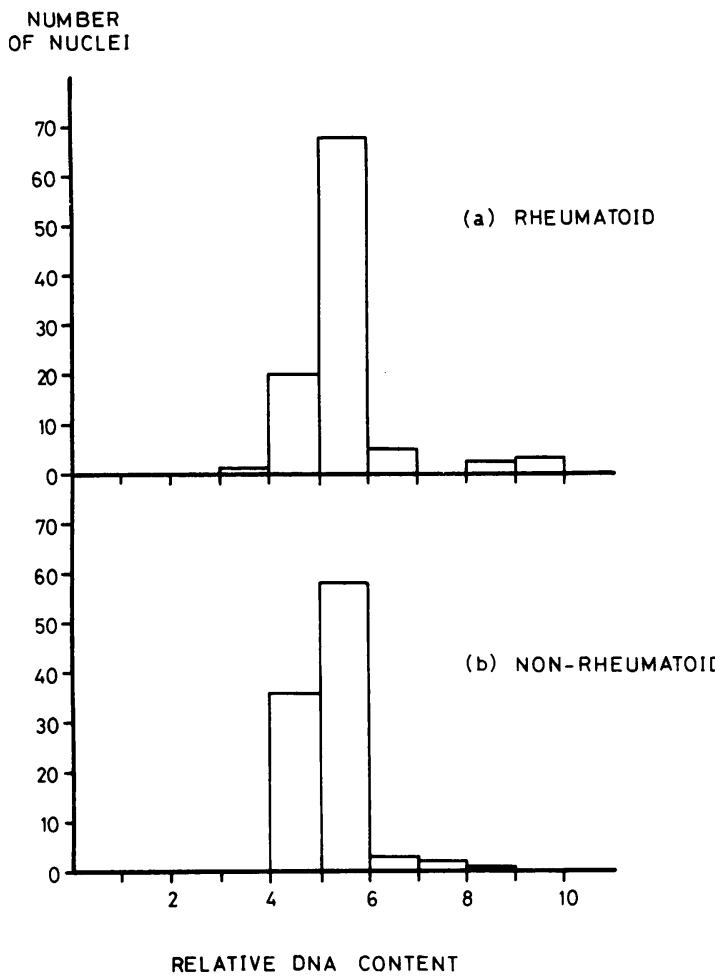

Fig. 4 Population histograms of the DNA content per nucleus from the lining cells of (a) rheumatoid and (b) nonrheumatoid synovial tissue. Both show a $2 c$ value of about 7 arbitrary units, and both show some nuclei with more than 8 units, indicating some synthesis of DNA

or not, in the rheumatoid and nonrheumatoid synoviocytes.

In one rheumatoid and 1 nonrheumatoid specimen the amount of DNA per nucleus in the cells of the deeper connective tissue-but acute and chronic inflammatory cells excluded-was measured (Fig. $5 a$ and $b$ ). There seemed little difference between the results from the 2 specimens. In 1 nonrheumatoid specimen the lining appeared to be in 2 layers separated by a small space. Measurement of the DNA content per nucleus in these 2 layers showed marked differences (Fig. 6a, b).

One specimen from a case of villonodular synovitis was also examined. Measurements were made in the outer (first 2-cell layer) and deeper (6 cells below the surface) synoviocytes and in the cells lining the villi (Fig. 7a, b, c).

DNA SYNTHESIS INDEX

The index of DNA synthesis was calculated from

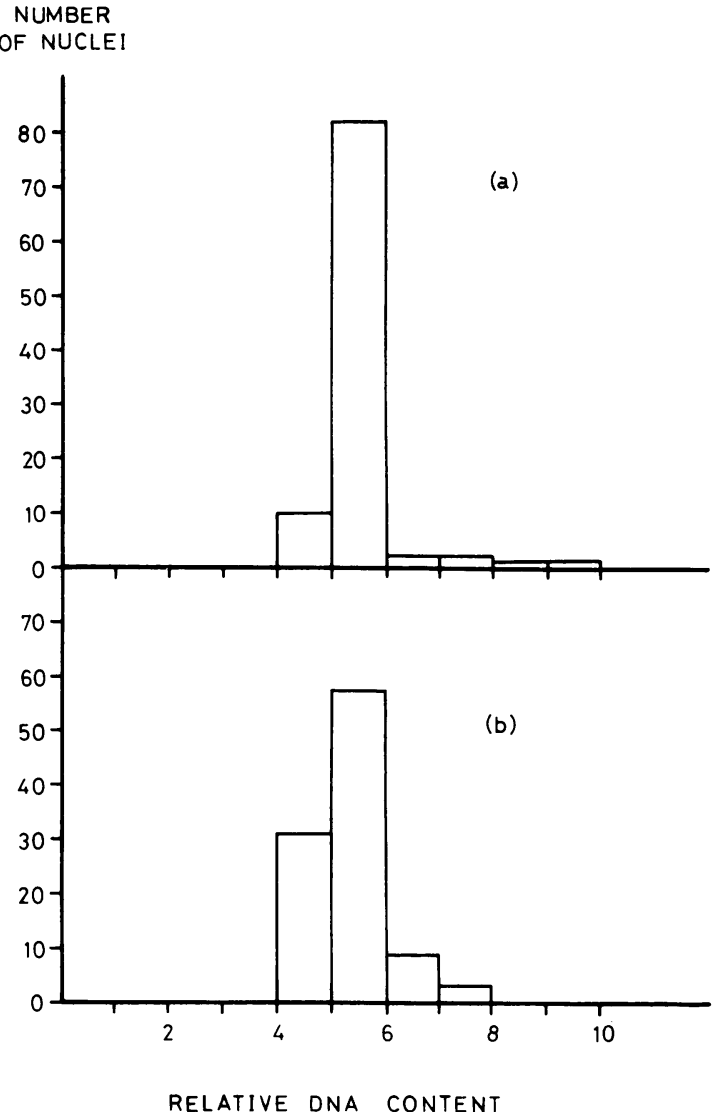

Fig. 5 Population histograms of the DNA content per nucleus in cells of the deeper connective tissue of (a) 1 rheumatoid and (b) 1 nonrheumatoid synovial membrane. Both show the same modal value (5-6 units) and some degree of DNA synthesis.

Feulgen cytophotometry of the lining cells of 12 rheumatoid and 12 nonrheumatoid specimens (Table 1). Individual indices ranged from $0 \cdot 7$ to $12 \cdot 4$, indicating either no appreciable synthesis (index of less than 3.0 ) or the degree of synthetic activity associated with a tissue that was slowly turning over. In a few samples (Table 2) the DNA content per nucleus was measured also in other cells of the tissue. In the rheumatoid specimen (1980) there was little difference in the DNA synthesis index in the cells of the lining layer and in cells, other than infiltrating inflammatory cells, deeper in the stroma. The same was true of one nonrheumatoid specimen (2219). In the other nonrheumatoid specimen (2220) the outer lining cells, which 


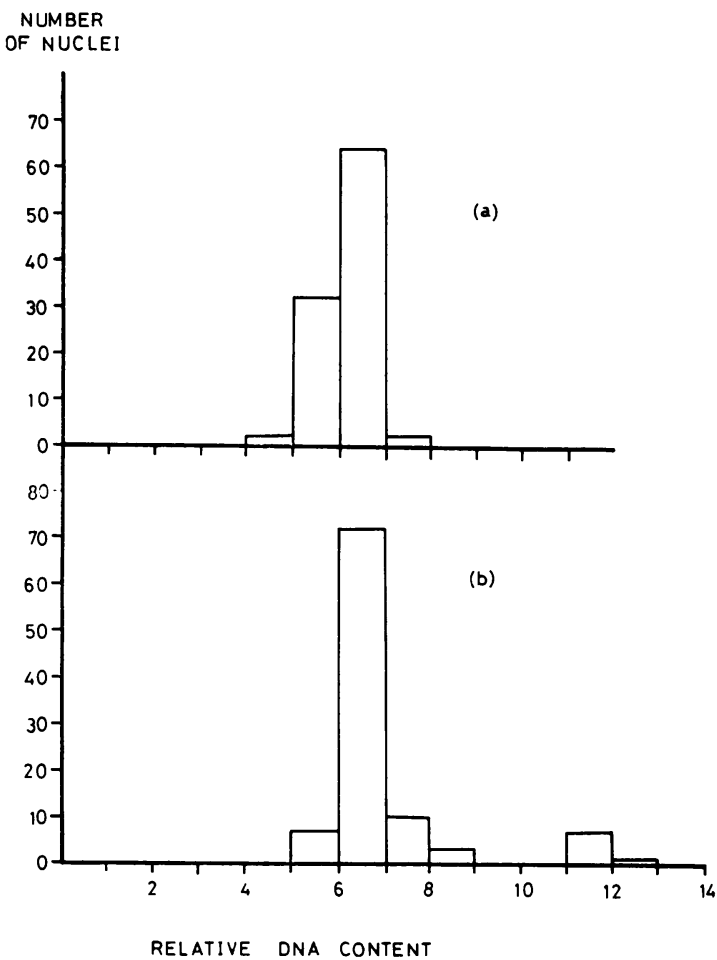

Fig. 6 Population histograms of the DNA content per nucleus in (a) the outer and (b) the inner layers of $a$ complex lining of a nonrheumatoid synovial membrane. There is no indication of synthesis in the former but clear indication of it in the latter, with some nuclei containing almost double the amount found at the modal value

Table 1 The DNA synthesis index measured in the lining cells of 12 rheumatoid and 12 nonrheumatoid specimens

\begin{tabular}{|c|c|c|c|}
\hline \multicolumn{2}{|l|}{ Rheumatoid } & \multicolumn{2}{|l|}{ Nonrheumatoid } \\
\hline Specimen no. & $\begin{array}{l}\text { DNA } \\
\text { synthesis } \\
\text { index }\end{array}$ & Specimen no. & $\begin{array}{l}\text { DNA } \\
\text { synthesis } \\
\text { index }\end{array}$ \\
\hline $\begin{array}{l}1599 \\
1612 \\
1677 \\
1681 \\
1692 \\
1696^{*} \\
1819 \\
1815 \\
1823 \\
1832 \\
1854 \\
1980 \\
\text { Mean } \pm \text { SEM } \\
0.25>\mathrm{P}>0.1\end{array}$ & $\begin{array}{c}5 \cdot 6 \\
12 \cdot 4 \\
0 \cdot 8 \\
6 \cdot 7 \\
3 \cdot 3 \\
0.9 \\
4 \cdot 0 \\
7 \cdot 6 \\
5 \cdot 5 \\
10 \cdot 8 \\
10 \cdot 4 \\
4 \cdot 4 \\
\pm 1 \cdot 1 \\
\text { udent's } t \text { test) }\end{array}$ & $\begin{array}{l}1595 \\
1632 \\
1655 \\
1665 \\
1667 \\
1685 \\
1701 \\
1702 \\
1704 \\
1824 \\
1869 \\
2219 \\
\text { Mean } \pm \text { SEM }\end{array}$ & $\begin{array}{c}3 \cdot 6 \\
6 \cdot 1 \\
0 \cdot 7 \\
3 \cdot 5 \\
3 \cdot 0 \\
5 \cdot 4 \\
2 \cdot 6 \\
10 \cdot 0 \\
4 \cdot 7 \\
6 \cdot 0 \\
0 \cdot 9 \\
1 \cdot 7 \\
0 \pm 0 \cdot 75\end{array}$ \\
\hline
\end{tabular}

*Psoriatic arthritis.

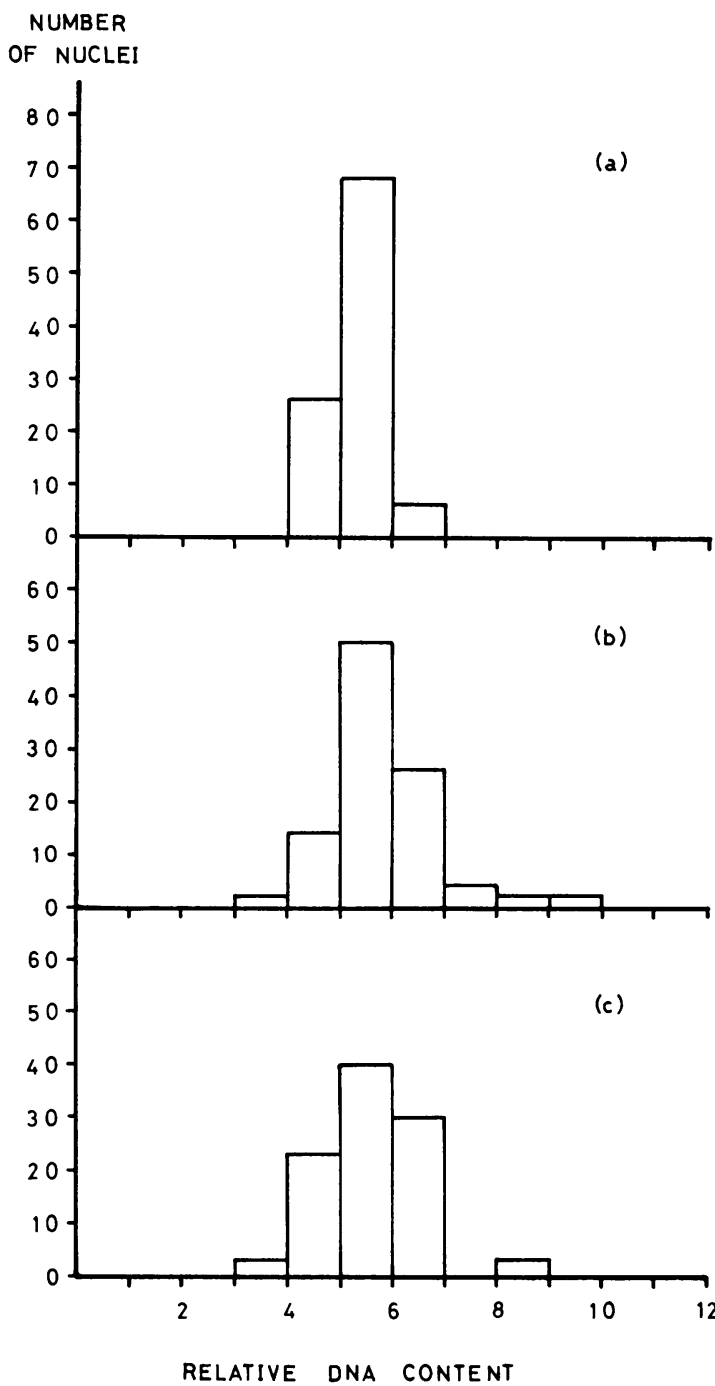

Fig. 7 Population histograms of the DNA content per nucleus in a specimen of villonodular synovitis measured in (a) the outer 1-2 cells of the lining; (b) at a depth of about 6 cells within the thickened lining; and (c) in the cells lining the villi

seemed to be histologically effete, had a very low index, but the lining below this layer had a markedly higher index, in agreement with its histological appearance. In the synovial tissue from the case of villonodular synovitis (1978) the index was markedly elevated both in the deeper layer of the synovial lining, about 6 cells below the surface of the hyperplastic lining, and in the cells lining villi. 
Table 2 The DNA synthesis index in the lining cells and other cells of synovial specimens

\begin{tabular}{|c|c|c|c|c|}
\hline \multirow{2}{*}{$\begin{array}{l}\text { Specimen } \\
\text { no. }\end{array}$} & \multirow{2}{*}{ Description } & \multicolumn{3}{|c|}{ DNA synthesis index } \\
\hline & & $\begin{array}{l}\text { Lining } \\
\text { cell layer } \\
\text { (outer } 1-2 \\
\text { cells) }\end{array}$ & $\begin{array}{l}\text { Lining } \\
\text { cell layer } \\
\text { (deeper } \\
\text { cells) }\end{array}$ & $\begin{array}{l}\text { Cells } \\
\text { of the } \\
\text { stroma }\end{array}$ \\
\hline 1978 & $\begin{array}{l}\text { Villinodular } \\
\text { synovitis: nonconvoluted } \\
\text { villi }\end{array}$ & $\begin{array}{l}0.85 \\
6 \cdot 5\end{array}$ & 8.0 & \\
\hline $\begin{array}{l}1980 \\
2219 \\
2220^{*}\end{array}$ & $\begin{array}{l}\text { Rheumatoid } \\
\text { Nonrheumatoid } \\
\text { Nonrheumatoid }\end{array}$ & $\begin{array}{l}4 \cdot 4 \\
1 \cdot 7 \\
0 \cdot 33\end{array}$ & $\frac{\overline{7}}{8 \cdot 1}$ & $\begin{array}{l}2 \cdot 9 \\
2 \cdot 5 \\
-\end{array}$ \\
\hline
\end{tabular}

*This specimen had 2 separate lining-cell layers; the outer layer appeared to be histologically effete.

\section{Discussion}

The Feulgen reaction for DNA involves removal of purines by acid hydrolysis to expose the aldehyde groups of the deoxyribose sugar; these groups are then coloured by Schiff's reagent. ${ }^{6}$ This hydrolysis is critical. Earlier workers used $1 \mathrm{~N} \mathrm{HCl}$ at $60^{\circ} \mathrm{C}$ for a particular period which was deemed to be optimal for this reaction done on some test material but not necessarily on each cell type investigated. Thus Mohr et al. ${ }^{2}$ fixed synovial lining cells with formalin, which influences the hydrolysis process, and hydrolysed in $0.5 \mathrm{~N} \mathrm{HC1}$ at $50^{\circ} \mathrm{C}$ for $60 \mathrm{~min}$, without demonstrating whether or not this was optimal. However, it has been shown that temperatures of $50-60^{\circ} \mathrm{C}$ break the DNA backbone and therefore can cause loss of DNA.10,11 Thus hydrolysis at lower temperatures is preferable for 2 reasons: firstly, because it retains the DNA longer within the chromatin, and secondly because it allows the clearer demonstration of different forms of DNA or DNA protein in the chromatin, each with its characteristic rate of hydrolysis. ${ }^{12-14}$

With most tissues acidic hydrolysis in $5 \mathrm{~N} \mathrm{HC1}$ at room temperature for $20 \mathrm{~min}$ is optimal. When this time was used (Fig. 2) there appeared to be more DNA per nucleus in the rheumatoid than in the nonrheumatoid cells. Thus it seemed as if the rheumatoid synoviocytes had a greater content of DNA than did their nonrheumatoid counterparts, indicating the apparent aneuploidy of synoviocytes grown in proliferative culture, as reviewed by Mohr et al. ${ }^{2}$ However, when the optimal time of hydrolysis (Fig. 1) for the rheumatoid and nonrheumatoid chromatin was used, the values were identical (Fig. 3). Apart from defining the optimal time of hydrolysis, these hydrolysis reaction graphs (Fig. 1) disclosed a point of some further interest, namely, that there was 1 component of the DNA of rheumatoid chromatin that hydrolysed more rapidly than the chromatin of nonrheumatoid nuclei, so giving higher values after $20 \mathrm{~min}$ of hydrolysis. Similar acid-labile fractions of DNA have been reported in active cells during embryogenesis ${ }^{12}$ and in malignant cells. ${ }^{13,15}$

The DNA population histograms of even nonrheumatoid synovial lining cells showed some degree of DNA synthesis (Fig. 4b) in agreement with the studies of Mohr et al. ${ }^{1}$ with tritiated thymidine. By simple inspection it was impossible to decide whether there was more or less synthesis in the rheumatoid specimens. The DNA synthesis index gave a quantitative measure of the amount of synthetic activity. We may take an index of up to 3 as indicating negligible or very little DNA synthesis; a value of 3-9 as indicating the level of DNA synthesis associated with a population that is slowly replacing itself with a low mitotic index (as in the basal cells of the epidermis of guinea-pig skin); and values of $10-23$ as indicating a regenerating system. ${ }^{9}$ By these criteria the indices of most of the rheumatoid and nonrheumatoid synovial lining-cell populations would be of the order expected from a population that was slowly renewing itself. It was noteworthy that there was no significant difference in the indices obtained from rheumatoid and nonrheumatoid synovial lining cells. It is also of some interest that the index agreed with the histological impression of greater cellular activity in the deeper cells and the cells lining the villi in the case of villonodular synovitis, and in the inner layer of the nonrheumatoid specimen (2220; Table 2) in which the outer layer appeared effete.

This work was supported by grants from the Medical Research Council and by general financial assistance from the Arthritis and Rheumatism Council for Research. We are indebted to Mr B. Cashman, FRCs, and to Mr A. Catterall, FRCS, for their active collaboration.

\section{References}

1 Mohr W, Beneke G, Mohing W. Proliferation of synovial lining cells and fibroblasts. Ann Rheum Dis 1975; 34: 219-224.

2 Mohr W, Beneke G, Mohing W. Zytophotometrische Untersuchungen zur Proliferation der Synovialzellen (lining cells) bei rheumatoider Arthritis. $Z$ Rheumatol 1973 ; 32: 428-440.

3 Nykänen P, Helve T, Kankaanpää U, Larsen A. Characterization of the DNA-synthesizing cells in rheumatoid synovial tissue. Scand J Rheumatol 1978; 7: 118-122.

4 Roels H. 'Metabolic' DNA: a cytochemical study. Int Rev Cytol 1966; 19: 1-34.

5 Ropes M W, Bennet G A, Cobb S, Jacox R, Jessar R A. Diagnostic criteria for rheumatoid arthritis. Ann Rheum Dis $1959 ; 18$ : 49.

6 Chayen J, Bitensky L, Butcher R G. Practical Histochemistry. New York and London: Wiley, 1973. 
7 Bitensky L, Butcher R G, Chayen J. Quantitative cytochemistry in the study of lysosomal function. In: Dingle $\mathrm{J} \mathrm{T}$, ed. Lysosomes in Biology and Pathology, vol. 3. Amsterdam: North Holland, 1973: 465-510.

8 Chayen J. Microdensitometry. In Slater T F, ed. Biochemical Mechanisms of Liver Injury. London and New York: Academic Press 1978: 257-291.

9 Coulton L A. (1977). The cytochemical measurement of DNA and its synthesis with particular reference to its involvement in rheumatological problems. $\mathrm{PhD}$ thesis, Brunel University.

10 Itikawa O, Ogura I. (1954). The Feulgen reaction after hydrolysis at room temperature. Stain Technol 1954; 29: $13-15$.

11 Jordanov J. On the transition of deoxyribonucleic acid to apurinic acid and the loss of the latter from tissues during
Feulgen reaction hydrolysis. Acta Histochem (Jena) 1963; 15: $135-152$.

12 Agrell I, Bergqvist H -A. Cytochemical evidence for varied DNA complexes in the nuclei of undifferentiated cells. J Cell Biol 1962; 15: 604-606.

13 Böhm N, Sandritter W. Feulgen hydrolysis of normal cells and mouse ascites tumour cells. J Cell Biol 1966; 28: $1-7$.

14 Rasch R W, Rasch E M. Kinetics of hydrolysis during the Feulgen reaction for deoxyribonucleic acid: a reevaluation. J Histochem Cytochem 1973; 21: 10531065.

15 Millett J A, Husain O A N, Analysis of chromatin in carcinoma-in-situ. In: eds. Quantitative Cytochemistry and Its Applications. Pattison J R, Bitensky L, Chayen J, London and New York: Academic Press, 1979. 